DOI: $10.31393 /$ reports-vnmedical-2020-24(3)-14

UDC: $618.15-002: 616-093-/ 098$

\title{
THE STRESS HORMONES EFFECT ON THE PROGRESSION OF VAGINAL BACTERIAL DYSBIOSIS
}

\section{Hruzevskiy O. A. ${ }^{1}$, Minukhin V. V. ${ }^{2}$}

${ }^{1}$ Odessa National Medical University (Valikhovsky Lane, 2, Odessa, Ukraine, 65000),

${ }^{2}$ Mechnikov Institute of Microbiology and Immunology of National Academy of Medical Sciences of Ukraine (street Pushkinska, 14, Kharkiv, Ukraine, 61057)

Annotation. The stress objective marker is the neuro-hormonal stress-implementing system stress and the increase the cortisol and prolactin levels in the blood, leading to the "distress syndrome" formation. Aim - to establish the stress effect, revealed according to the level of stress- implementing hormones, in particular cortisol and prolactin, on the progression of vaginal bacterial dysbiosis and the bacterial vaginosis (BV) development. During the study there were used the data taken from 298 women, who were divided into the following groups according to the Opportunistic pathogenic microflora index (OPMI) and normobiota index (NBI): normocenosis $(n=53)$, dysbiosis I $(n=128)$ and II degree $(n=117)$ among the latter 83 patients with $N B />1$ lg GE/sample were identified, in which BV was established. Molecular genetic studies of the epithelium scraping from the vagina posterolateral wall were carried out by Polymerase chain reaction ("DNK-Technologiia" LLC, RF). Facultative and obligate anaerobes, myco-and ureplasmas, and yeast-like fungi were quantified. The cortisol and prolactin blood levels were identified. For statistical analysis, the Statistica 10 software (StatSoft, Inc., USA) was used. Catch out that the blood cortisol content with dysbiosis progression compared with the normocenosis has changed in two-phase: it was increased with I degree dysbiosis (1.2-1.4 times; $p<0.01)$ and decreased with II degree dysbiosis and BV (1.5 times; $p<0.001)$. So, with respect to the classical concept of the General adaptive syndrome of $G$. Selye, the first dysbiosis development stages can be considered as reaction of "anxiety", while the development of BV is a reaction of "exhaustion". The blood prolactin content compared with normocenosis with dysbiosis was increased, which was most expressed in BV (1.5 times; $p<0.001)$. It also reflected the stress response development with increased central nervous system stress. The blood hormones content has relation with BV-associated microbiota indexes: prolactin was positively related with NBI, and cortisol was negatively related to the number of Atopobium vaginalis. Thus, according to the data obtained, BV can be attributed to the stress pathology with the "distress syndrome" development and the content of cortisol and prolactin in the blood can be considered as marker factors for hormonal regulation disorder.

Keywords: bacterial vaginosis, stress, cortisol, prolactin.

\section{Introduction}

Bacterial vaginosis (BV) is the most common lower genital tract infection in women of reproductive age [3, 21]. According to study data [6], women with the highest risk of BV are young, unmarried, low-income, low-educated and African-American. The "stressors" are social problems, such as poverty, poor housing and neighborhoods, high crime rates, and discrimination. The authors [6] proved a statistically significant, independent of other factors, the effect of stress on the risk of BV. Psychosocial stress is associated with an overall prevalence (OR 1.10; $95 \% \mathrm{Cl}$ 1.01-1.20) and an increase in the incidence of BV (OR 1.29; $95 \% \mathrm{Cl} 1.12-1.48$ ) [20]. Maternal infection, especially BV during pregnancy, is one of the main causes of adverse perinatal consequences: it was found that women with moderate and high levels of stress were 2.3 times and 2.2 times, respectively, more likely to have BV [5].

The condition of vaginal microbiota depends on hygienic skills, sexual behavior, stress, as well as on physiological or pathological fluctuations in the level of female hormones [15]. Since the basis of BV is the uncontrolled growth of anaerobic bacteria [19] and the reduction of vaginal colonization resistance [10], the authors [11] hypothesized the suppression of immune function by stress, which increases the risk of BV. A higher prevalence of $B V$ has been found in women with high levels of general stress. A close relationship between stress levels, immune suppression, and changes in vaginal microbiota has been shown in a retrospective cohort study $(n=2439$; OR 1.015; $95 \% \mathrm{Cl} 1.005-1.026$ ) [25].

An objective marker of stress is the tension of the neurohormonal stress-implementing system - the axis of the hypothalamus-pituitary-adrenal cortex [8, 13]. In this case, the state of initial stress with increasing blood levels of corticotropin and cortisol changes to prolonged depletion of functional reserves of this system, which is the basis for the formation of the so-called "distress syndrome" [23]. It has been shown [7] that the morning rise in cortisol levels in saliva decreases in women with recurrent vulvovaginal candidiasis, which is a manifestation of chronic stress. In pregnant women with high levels of psycho-emotional stress (anxiety), the risk of BV was doubled, and they also had increased levels of stress hormones in the blood [12]. In pregnant women with urogenital infections, there was a significant increase in cortisol levels in the blood, starting from 19 weeks of pregnancy [22].

Another recognized hormone of stress is prolactin, 
which in addition to lactation regulates metabolic homeostasis, including control of body weight and adipose tissue, the response of the adrenal glands to stress, control of maternal behavior [1]. Hyperprolactinemia often accompanies BV, exacerbates pituitary and ovarian dysfunction and worsens the results of balneotherapy of such patients [2]. The level of prolactin in the blood can be used as a prognostic factor and a criterion for the effectiveness of therapy in women with diseases of the genital system, in particular - BV [14].

Thus, it is important to study the content of stress hormones in the blood, in particular - cortisol and prolactin, and to establish their influence on the progression of vaginal bacterial dysbiosis and the development of BV.

The aim of the study was to determine the effect of stress, determined by the level of stress-releasing hormones, in particular cortisol and prolactin, on the progression of vaginal bacterial dysbiosis and the development of bacterial vaginosis (BV).

\section{Materials and methods}

The study used data from 298 women aged 16 to 64 years who consulted a gynecologist for a preventive examination or complaints of discomfort in the genital area. The exclusion criterion was the presence of unduly pathogenic microorganisms in the scrapings of the vaginal epithelium (Trichomonas vaginalis, Neisseria gonorrhoeae, Chlamydia trachomatis and Herpes Simplex Virus 1,2). The presence in the vaginal swabs of more than 15-20 leukocytes in the field of view, which indicated the presence of an inflammatory reaction, was also a criterion for exclusion.

During the examination, a scraping of the epithelium was taken from the posterior wall of the vagina using a urogenital probe. Molecular genetic studies were performed by polymerase chain reaction (PCR). DNA was isolated using a set of reagents "Proba-HS" (LLC "DNA Technology", Russia). Amplification of test tubes with the reaction mixture was performed in the amplifier "DTLite" (LLC "DNA Technology", Russia). To study the state of the vaginal biocenosis, we used the "Femoflor 16" test system, which is designed for real-time PCR. The microbiota was quantified according to the following indicators [16]: total bacterial mass (TBM), normobiota (Lactobacillus spp.), obligate anaerobes (OA; Atopobium vaginalis, Eubacterium spp., Gardnerella vaginalis, Prevotella bivia, Porphyromonas spp., Lachnobacterium spp., Clostridium spp., Megasphaera spp., Veilonella spp., Dialister spp., Mobiluncus spp., Corynebacterium spp., Peptostreptococ spp., Sneathia spp., Leptotrihia spp., Fusobacterium spp.), facultative anaerobes (FA; Enterobacteriaceae spp., Staphylococcus spp., Streptococcus spp.), and myco- and ureaplasmas (MU; Ureaplasma urealiticum + parvum, Mycoplasma hominis + genitalium) and yeast-like fungi (YLF; Candida spp.).

The criterion for dividing patients into groups was the index of opportunistic pathogenic microflora (OPM), which was calculated as the difference between the sum of all opportunistic pathogens and the number of lactobacilli (in Ig GE/sample). In the normocenosis OPM was lower than -3 Ig GE/sample (1st group; $n=53$ ), in dysbiosis of the first degree OPM was in the range from -3 to $-1 \mathrm{lg}$ GE/sample (2nd group; $n=128$ ) and in dysbiosis of the second degree OPM was more than $-1 \mathrm{lg}$ GE/sample (3rd group; $n=117$ ) [9].

Groups with dysbiosis were divided into subgroups by normobiota indicator (NBI), which was calculated as the difference between total bacterial mass (TBM) and the number of lactobacilli (in Ig GE/sample). In the 2 nd group there are three subgroups: 1st - with NBI?0.3 Ig GE/sample $(n=23)$, 2nd - with NBI from 0.3 to $1.0 \mathrm{lg}$ GE/sample $(n=83)$ and the $3 r d$ - with NBI>1 lg GE/sample $(n=22)$. In the 3rd group there are two subgroups: 1st - with NBI?1 lg GE/ sample $(n=34)$ and $2 n d$ - with NBI>1 lg GE/sample $(n=83)$. In the last subgroup, the degree of dysbiosis was maximal and corresponded to the state of BV [9].

All patients underwent fasting blood sampling from the cubital vein in the amount of 3-4 ml. Blood tubes were centrifuged to obtain serum. The content of prolactin and cortisol was determined in the blood serum by enzymelinked immunosorbent assay using sets of reagents produced by NPL "Granum" (Ukraine). The content of hormones was determined in generally accepted units and compared with the norm [24].

Arithmetic mean $(M)$ and mean error $(m)$ were used for descriptive data statistics. Paired independent data samples were compared according to the Mann-Whitney (U) test. Significance of all differences was taken at $p<0.05$. To determine the relationship of species of microbial biocenosis with the content of hormones used regression analysis - a method of detecting the influence of one or more independent (factor) variables on their dependent performance variable (Statistica 10; StatSoft, Inc., USA).

\section{Results. Discussion}

The obtained results showed that the content of cortisol in the blood as the dysbiosis progressed changed in two phases: - was increased in the 1 st $(1.2$ times; $p=0.005)$ and in the 2nd subgroup (1.4 times; $p<0.001)$ of the 2 nd group (Table 1).

In the 3rd subgroup of the 2nd group the content of cortisol did not differ significantly from that in the 1st group $(p=0.848)$, while in the 2 nd group (grade II dysbiosis) the hormone content was significantly lower compared to the 1st group (normocenosis) - in 1.3-1.5 times $(p<0.001)$, which was more typical for the 2 nd subgroup - ie patients with BV (1.5 times; $p<0.001)$.

Thus, the obtained data indicate that as the dysbiosis progressed, there was an initial activation of the main stress-implementing system of the body - hypothalamicpituitary-corticoadrenal (in initial and moderate dysbiosis), while in the deepening degree of dysbiosis (severe 
Table 1. The content of hormones in the blood $(\mathrm{M} \pm \mathrm{m})$.

\begin{tabular}{|c|c|c|c|}
\hline \multicolumn{2}{|c|}{ Groups and subgroups } & $\begin{array}{c}\text { cortisol, } \\
\mathrm{nmol} / \mathrm{L}\end{array}$ & $\begin{array}{l}\text { prolactin, } \\
\mathrm{nmol} / \mathrm{L}\end{array}$ \\
\hline \multicolumn{2}{|c|}{1 group (normocenosis, $n=53$ ) } & $336,7 \pm 14,1$ & $8,50 \pm 0,31$ \\
\hline \multirow{3}{*}{$\begin{array}{l}2 \text { group (dysbiosis } \\
\text { of the I degree, } \\
n=128)\end{array}$} & 1 subgroup, $n=23$ & $407,9 \pm 19,6$ & $8,30 \pm 0,35$ \\
\hline & 2 subgroup, $n=83$ & $478,7 \pm 7,6$ & $8,48 \pm 0,14$ \\
\hline & 3 subgroup, $n=22$ & $344,5 \pm 26,9$ & $12,41 \pm 0,33$ \\
\hline \multirow{2}{*}{$\begin{array}{c}3 \text { group (dysbiosis } \\
\text { of the II degree, } \\
n=117 \text { ) }\end{array}$} & 1 subgroup, $n=34$ & $251,0 \pm 6,3$ & $12,25 \pm 1,12$ \\
\hline & 2 subgroup, $n=83$ & $231,2 \pm 4,4$ & $13,06 \pm 0,24$ \\
\hline \multicolumn{4}{|c|}{ Statistical procedure for comparing results } \\
\hline \multicolumn{2}{|l|}{$\mathrm{p}(\mathrm{MW})^{1}$} & 0,005 & 0,821 \\
\hline \multicolumn{2}{|l|}{$\mathrm{p}(\mathrm{MW})^{2}$} & $<0,001$ & 0,897 \\
\hline \multicolumn{2}{|l|}{$\mathrm{p}(\mathrm{MW})^{3}$} & 0,848 & $<0,001$ \\
\hline \multicolumn{2}{|l|}{$\mathrm{p}(\mathrm{MW})^{4}$} & $<0,001$ & 0,025 \\
\hline \multicolumn{2}{|l|}{$\mathrm{p}(\mathrm{MW})^{5}$} & $<0,001$ & $<0,001$ \\
\hline \multicolumn{2}{|l|}{$\mathrm{F}$} & 104,9 & 34,8 \\
\hline \multicolumn{2}{|l|}{$P$} & $<0,001$ & $<0,001$ \\
\hline
\end{tabular}

Notes: probability of discrepancies using the Mann-Whitney $\mathrm{U}$ test between the corresponding indicators in the 1st group and: $p(M W)^{1}$ - in the 1st subgroup of the 2nd group, $p(M W)^{2}-$ in the 2 nd subgroup of the 2 nd groups, $\mathrm{p}(\mathrm{MW})^{3}$ - in the 3 rd subgroup of the 2nd group, $p(M W)^{4}-$ in the 1 st subgroup of the 3rd group, $p(M W)^{5}$ - in the 2nd subgroup of the 3rd group; $F$ - the result and $p$ - the probability of analysis of variance to assess the differences of the respective indicators between subgroups.

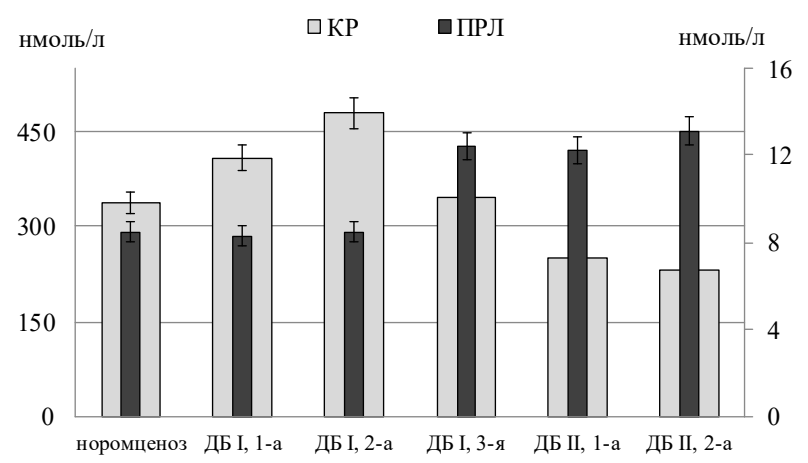

Fig. 1. Blood content of cortisol ( $\mathrm{nmol} / \mathrm{L})$ and prolactin $(\mathrm{nmol} / \mathrm{L})$ depending on the degree of dysbiosis; DB I and DB II - vaginal bacterial dysbiosis of I and II degree; 1st, 2nd, 3rd - subgroups; the statistical significance of the differences is shown in table 1.

dysbiosis, especially BV) this system has undergone functional exhaustion. The two-phase type of reaction of the system clearly reflected the content of cortisol in the blood (Fig. 1).

The level in the blood of another stress hormone prolactin (see Table 1 and Fig. 1) in the 1st and 2nd subgroups of the 2 nd group did not differ from that in the 1 st group ( $p>0.08$ ). In the 3rd subgroup of the 2 nd group and in the 3 rd group (both subgroups) it significantly exceeded that in the 1 st group $(p<0.03)$. The maximum level of prolactin was increased in the 2 nd subgroup of the 3rd group, ie - at BV (1.5 times; $p<0.001)$. This result also reflected tension of stress response, as increasing the activity of the infectious process increases the level of tension of the central nervous system $[13,23]$.

Analyzing the reaction of the adrenal glands in terms of the classical concept of $\mathrm{G}$. Selye on the development of general adaptation syndrome [23], we can identify a certain stage of its development. "Anxiety" reactions correspond to the first stages of dysbiosis (grade I dysbiosis), while the development of severe dysbiosis (grade II dysbiosis and $\mathrm{BV})$ reflects the "exhaustion" reaction. These results give grounds to attribute BV to stress pathology with the development of "distress syndrome".

The presence of significant trends that showed changes in the content of hormones in the blood with the progression of dysbiosis and BV, proved by the results of analysis of variance (see Table 1): the value of $F$ for cortisol and prolactin was 104.9 and 34.8 , respectively $(p<0.001)$.

According to the discriminant analysis, the division of patients into groups reflected the content of cortisol in the blood (Wilks'-Lambda test 0.018; $F=47.5 ; p<0.001$ ). That is, the tension of the main stress-implementing system the hypothalamic-pituitary-corticoadrenal, was the determining factor that differentiated other processes.

Thus, the reaction of hormonal stress-releasing systems in dysbiosis and BV was accompanied by the development of distress syndrome with hypocorticism and hyperprolactinemia, and the content of cortisol and prolactin in the blood can be considered as marker factors of such disorders.

According to regression analysis in grade I dysbiosis, the level of prolactin had a positive relationship with NBI (?coefficient $0.032 ; p=0.016$ ), ie - reflected the growth of BVassociated microbiota. Thus, in the stage of "anxiety" of the general adaptation syndrome, the degree of hyperprolactinemia was important for activating the growth of representatives of the microbial biocenosis of the vagina. This could be explained by the stress-activating effect of the hormone on the body's systems, and in particular - the gonadal system [1].

In grade II dysbiosis, regression analysis showed a negative correlation between the content of cortisol in the blood and the amount of Atopobium vaginalis. It is the last anaerobe, next to Gardnerella vaginalis, Megasphaera spp., Dialister spp., Sneathia spp. and Mycoplasma hominis belong to BV-marker habitats [17]. Atopobium vaginalis plays an important role in the pathophysiology of $\mathrm{BV}$, is part of the microbial biofilms that determine the resistance of pathogenic microbiota to the action of antimicrobial substances. In addition, dysbiosis and, especially, BV are characterized by a decrease in systemic and local inflammatory reactions [18], which correlates with an increase in the number of pathogenic flora [4].

The results obtained on the correlation of stress hormones (cortisol and prolactin) with the degree of bacterial dysbiosis indicate the involvement of neurohormonal regulation in the pathogenesis of $\mathrm{BV}$ through the 
formation of "distress syndrome" with hypocorticism and hyperprolactinemia. Psycho-emotional stress, which is of great importance in the formation of BV $[20,25]$, realizes its pathogenic effect precisely because of the violation of hormonal regulation of the reproductive system and the microbiome of the vagina. Also, our results confirm the formation of pathological hormonal-microbiota-immune system in vaginal bacterial dysbiosis and BV [26], and the content of cortisol and prolactin can be considered as marker factors of hormonal regulation.

\section{Conclusions and prospects for further development}

1. The content of cortisol in the blood as the dysbiosis progressed in comparison with the normocenosis changed in two phases: it was increased in grade I dysbiosis and decreased in grade II dysbiosis and BV. Thus, focusing on the classical concept of the general adaptation syndrome

\section{References}

1. Bernard, V., Young, J., \& Binart, N. (2019). Prolactin - a pleiotropic factor in health and disease. Nat. Rev. Endocrinol., 15 (6), 356-365. doi: 10.1038/s41574-019-0194-6

2. Boldyreva, O. A. (2015). The influence of balneo- and peloid therapy on the characteristics of the hormonal regulation in the women presenting with bacterial vaginosis. Vopr. Kurortol. Fizioter. Lech. Fiz. Kult., 92 (3), 22-26. doi: 10.17116/ kurort2015322-26

3. Coudray, M. S., \& Madhivanan, P. (2020). Bacterial vaginosis A brief synopsis of the literature. Eur. J. Obstet. Gynecol. Reprod. Biol., 245, 143-148. doi: 10.1016/j.ejogrb.2019.12.035

4. Cox, C., Watt, A. P., McKenna, J. P., \& Coyle, P. V. (2016). Mycoplasma hominis and Gardnerella vaginalis display a significant synergistic relationship in bacterial vaginosis. Eur. J. Clin. Microbiol. Infect. Dis., 35 (3), 481-7. doi: 10.1007/ s10096-015-2564-x

5. Culhane, J. F., Rauh, V., McCollum, K. F., Hogan, V. K., Agnew, K., \& Wadhwa, P. D. (2001). Maternal stress is associated with bacterial vaginosis in human pregnancy. Matern. Child Health J., 5 (2), 127-34. doi: 10.1023/a:1011305300690

6. Culhane, J. F., Rauh, V. A., \& Goldenberg, R. L. (2006). Stress, bacterial vaginosis, and the role of immune processes. Curr. Infect. Dis. Rep., 8 (6), 459-64. doi: 10.1007/s11908-0060020-x

7. Ehrstrom, S. M., Kornfeld, D., Thuresson, J., \& Rylander, E. (2005). Signs of chronic stress in women with recurrent candida vulvovaginitis. Am. J. Obstet. Gynecol., 193 (4), 137681. doi: 10.1016 / j.ajog.2005.03.068

8. Fogelman, N., \& Canli, T. (2018). Early life stress and cortisol: A meta-analysis. Horm. Behav., 98, 63-76. doi: 10.1016/ j.yhbeh.2017.12.014

9. Gruzevskyy, O. A., \& Vladymirova, M. P. (2014). The results of a complex bacteriological study of vaginal contents under the conditions of bacterial vaginosis. Advances in biology and medicine, 2, 54-7

10. Gruzevskyy, A. A. (2019). Colonization resistance of vaginal secretion. Journal of Education, Health and Sport, 9 (2), 58395. doi: http://dx.doi.org/10.5281/zenodo.39931

11. Harville, E. W., Hatch, M. C., \& Zhang, J. (2005). Perceived life stress and bacterial vaginosis. J. Womens Health (Larchmt), 14 (7), 627-33. doi: 10.1089/jwh.2005.14.627

12. Harville, E. W., Savitz, D. A., Dole, N., Thorp, J. M. Jr., \& Herring, A. H. (2007). Psychological and biological markers of stress of $\mathrm{G}$. Selye, the first stages of dysbiosis can be considered a reaction of "anxiety", while the development of BV - a reaction of "exhaustion".

2. The content of prolactin in the blood in comparison with the normocenosis in dysbiosis was increased, which was most pronounced at BV. It also reflected the development of a stress response and increased tension of the central nervous system.

3. According to the regression analysis, the content of hormones in the blood was related to the indicators of BVassociated microbiota: prolactin was positively associated with NBI, and cortisol - negatively with the amount of Atopobium vaginalis.

According to the obtained data, severe dysbiosis and $\mathrm{BV}$ are characterized by the development of "distress syndrome", and the content of cortisol and prolactin in the blood can be considered as marker factors of hormonal dysregulation.

and bacterial vaginosis in pregnant women. BJOG, 114 (2), 216-23. doi: 10.1111/j.1471-0528.2006.01209.x

13. Jonsdottir, I. H., \& Sj?rs Dahlman, A. (2019). Mechanisms in endocrinology: Endocrine and immunological aspects of burnout: a narrative review. Eur. J. Endocrinol., 1, 180 (3), R147-R158. doi: 10.1530/EJE-18-0741

14. Kaladze, N. N., \& Boldyreva, O. A. (2017). The influence of the comprehensive SPA and health resort-based treatment on the system of hormonal regulation in the women presenting with gynecological pathology depending on the plasma prolactin level. Vopr. Kurortol. Fizioter. Lech. Fiz. Kult., 94 (2), 47-52. doi: 10.17116/kurort201794247-52

15. Kaur, H., Merchant, M., Haque, M. M., \& Mande, S. S. (2020). Crosstalk between female gonadal hormones and vaginal microbiota across various phases of women's gynecological lifecycle. Front Microbiol., 11, 551. doi: 10.3389/ fmicb.2020.00551

16. Lipova, E. V., Boldyreva, M. N., Trofimov, DYu, \& Vitvitskaya, Yu. G. (2015). Femoflor. Urogenital infections caused by opportunistic biota in women of reproductive age (clinical and laboratory diagnostics). Manual for doctors. Moscow: DNA technology.

17. Mendling, W., Palmeira-de-Oliveira, A., Biber, S., \& Prasauskas, V. (2019). An update on the role of Atopobium vaginae in bacterial vaginosis: what to consider when choosing a treatment? A mini review. Arch. Gynecol. Obstet., 300 (1), 16. doi: 10.1007/s00404-019-05142-8

18. Muzny, C. A., \& Schwebke, J. R. (2016). Pathogenesis of bacterial vaginosis: discussion of current hypotheses. J. Infect. Dis., 214 (1), S1-5. doi: 10.1093/infdis/jiw121

19. Muzny, C. A., Taylor, C. M., Swords, W. E., Tamhane, A., Chattopadhyay, D., Cerca, N., \& Schwebke J. R. (2019). An updated conceptual model on the pathogenesis of bacterial vaginosis. J. Infect. Dis., 220 (9), 1399-1405. doi: 10.1093/ infdis/jiz342

20. Nansel, T. R., Riggs, M. A., Yu, K. F., Andrews, W. W., Schwebke, J. R., \& Klebanoff, M. A. (2006). The association of psychosocial stress and bacterial vaginosis in a longitudinal cohort. Am. J. Obstet. Gynecol., 194 (2), 381-6. doi: 10.1016/ j.ajog.2005.07.047

21. Nasioudis, D., Linhares, I. M., Ledger, W. J., \& Witkin, S. S. (2017). Bacterial vaginosis: a critical analysis of current knowledge. BJOG, 124 (1), 61-69. doi: 10.1111/1471- 
0528.14209

22. Ruiz, R. J., Fullerton, J., Brown, C. E., \& Schoolfield, J. (2001). Relationships of cortisol, perceived stress, genitourinary infections, and fetal fibronectin to gestational age at birth. Biol. Res. Nurs., 3 (1), 39-48. doi: 10.1177/ 109980040100300106

23. Szabo, S., Yoshida, M., Filakovszky, J., \& Juhasz, G. (2017). "Stress" is 80 Years Old: From Hans Selye Original Paper in 1936 to Recent Advances in GI Ulceration. Curr. Pharm. Des., 23 (27), 4029-4041. doi: 10.2174/ 1381612823666170622110046
24. Tits, N. U. (1997). Encyclopedia of clinical laboratory tests. Moscow: Labinform.

25. Turpin, R., Brotman, R. M., Miller, R. S., Klebanoff, M. A., He, X., \& Slopen, N. (2019). Perceived stress and incident sexually transmitted infections in a prospective cohort. Ann Epidemiol., 32, 20-27. doi: 10.1016/j.annepidem.2019.01.010

26. Vitali, D., Wessels, J. M., \& Kaushic, C. (2017). Role of sex hormones and the vaginal microbiome in susceptibility and mucosal immunity to HIV-1 in the female genital tract. AIDS Res. Ther., 14 (1), 39. doi: 10.1186/s12981-017-0169-4

\section{ВПЛИВ СТРЕСОВИХ ГОРМОНІВ НА ПРОГРЕСУВАННЯ ВАГІНАЛЬНОГО БАКТЕРІАЛЬНОГО ДИСБІОЗУ Грузевський О. А., Мінухін В. В.}

Анотація. Об'єктивним маркером стресу є напруження нейро-гормональної стрес-реалізуючої системи та збільшення вмісту у крові кортизолу та пролактину, що обумовлює формування "дистрес-синдрому". Мета дослідження - встановити вплив стресу, визначеного за рівнем стрес-реалізуючих гормонів, зокрема - кортизолу та пролактину, на прогресування вагінального бактеріального дисбіозу та розвиток бактеріального вагінозу (БВ). Залучені дані 298 жінок, які за індексом умовно-патогенної мікрофолори (ІУПМ) та показником нормобіоти (ПНБ) були розподілені на групи: нормоценоз ( $n=53$ ), дисбіоз I (n=128) і II ступеню (n=117); серед останніх виокремлено 83 пацієнтки з ПНБ>1 lg ГЕ/зразок, в яких був встановлений БВ. Молекулярно-генетичні дослідження зіскрібка епітелію з задньобокової стінки піхви проводили методом полімеразної ланцюгової реакції ("ДНК-технологія", РФ). Кількісно визначали фракультативні й облігатні анаероби, міко- $і$ уреплазми та дріжджоподібні гриби. У крові визначали вміст кортизолу та пролактину. Для статистичного аналізу використовували програму Statistica 10 (StatSoft, Inc., USA). Виявлено, що вміст у крові кортизолу по мірі прогресування дисбіозу у порівнянні з нормоценозом змінювався двофразно: був збільшеним при дисбіозі I ступеню (у 1,2-1,4 рази; $p<0,01) i$ - зниженим при дисбіозі II ступеню і БВ (у 1,5 рази; р<0,001). Отже, орієнтуючись на класичну концепцію загального адаптаційного синдрому Г. Сельє, перші стадії розвитку дисбіозу можна вважати реакцією "тривоги", тоді як розвиток БВ, - реакцією "виснаження". Вміст у крові пролактину у порівнянні з нормоценозом при дисбіозі виявився збільшеним, що було максимально виражено при БВ (у 1,5 рази; p<0,001). Це також відбивало розвиток стресової реакції з підвищенням напруженості центральної нервової системи. Вміст у крові гормонів мав зв'язок з показниками БВ-асоційованої мікробіоти: пролактин був позитивно зв'язаний з ПНБ, а кортизол - негативно з кількістю Atopobium vaginalis. Отже відповідно до отриманих даних, БВ можна віднести до стресової патології з розвитком "дистрес-синдрому", а вміст у крові кортизолу і пролактину можна розглядати як маркерні чинники порушення гормональної регуляції.

Ключові слова: бактеріальний вагіноз, стрес, кортизол, пролактин.

\section{ВЛИЯНИЕ СТРЕССОВЫХ ГОРМОНОВ НАПРОГРЕССИРОВАНИЕ ВАГИНАЛЬНОГО БАКТЕРИАЛЬНОГО ДИСБИОЗА Грузевский А. А., Минухин В. В.}

Аннотация. Объективным маркером стресса является напряжение нейро-гормональной стресс-реализующей системы и увеличение содержания в крови кортизола и пролактина, что обусловливает формирование "дистресс-синдрома". Цель исследования - установить влияние стресса, определенного по уровню стресс-реализующих гормонов, в частности кортизола и пролактина, на прогрессирование вагинального бактериального дисбиоза и развитие бактериального вагиноза (БВ). Были использованы данные 298 женщин, которые по индексу условно-патогенной микрофрлоры (ИУПМ) и показателю нормобиоты (ПНБ) были распределены на группы: нормоценоз ( $n=53)$, дисбиоз I ( $n=128)$ и II степени $(n=117)$ среди последних выделены 83 пациентки с ПНБ>1 lg ГЭ/образец, у которых был установлен БВ. Молекулярно-генетические исследования соскоба эпителия с заднебоковой стенки влагалища проводили методом полимеразной цепной реакции ("ДНКтехнология", РФ). Количественно определяли факультативные и облигатные анаэробы, мико- и уреплазмы и дрожжеподобные грибы. В крови определяли содержание кортизола и пролактина. Для статистического анализа использовали программу Statistica 10 (StatSoft, Inc., USA). Выявлено, что содержание в крови кортизола по мере прогрессирования дисбиоза по сравнению с нормоценозом менялся двухфазно: был увеличенным при дисбиозе I степени (в 1,2-1,4 раза; p<0,01) и пониженным - при дисбиозе II степени и БВ (в 1,5 раза; р<0,001). Итак, ориентируясь на классическую концепцию общего адаптационного синдрома Г. Селье, первые стадии развития дисбиоза можно считать реакцией "тревоги", тогда как развитие БВ - реакцией "истощение". Содержание в крови пролактина по сравнению с нормоценозом при дисбиозе оказался увеличенным, что было максимально выражено при БВ (в 1,5 раза; $p<0,001)$. Это также отражало развитие стрессовой реакции с повышением напряженности центральной нервной системы. Содержание в крови гормонов имело связь $c$ показателями БВ-ассоциированной микробиоты: пролактин был положительно связан с ПНБ, а кортизол - отрицательно с количеством Atopobium vaginalis. Итак, согласно полученным данным, БВ можно отнести к стрессовой патологии с развитием "дистресс-синдрома", а содержание в крови кортизола и пролактина можно рассматривать как маркерные фракторы нарушения гормональной регулящии.

Ключевые слова: бактериальный вагиноз, стресс, кортизол, пролактин. 